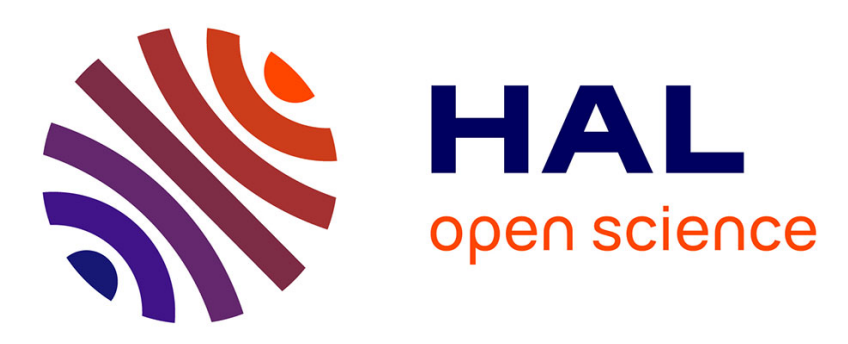

\title{
A filter affinity transfer method for the analysis of rheumatoid factors.
}

Pierre Aucouturier, Jean-Paul Maillochon, Guy Joseph-Théodore, Françoise Duarte, Jean-Louis Preud'Homme

\section{> To cite this version:}

Pierre Aucouturier, Jean-Paul Maillochon, Guy Joseph-Théodore, Françoise Duarte, Jean-Louis Preud'Homme. A filter affinity transfer method for the analysis of rheumatoid factors.. Journal of Clinical Laboratory Analysis, 1991, 5 (6), pp.378-81. inserm-01899804

\section{HAL Id: inserm-01899804 https://www.hal.inserm.fr/inserm-01899804}

Submitted on 19 Oct 2018

HAL is a multi-disciplinary open access archive for the deposit and dissemination of scientific research documents, whether they are published or not. The documents may come from teaching and research institutions in France or abroad, or from public or private research centers.
L'archive ouverte pluridisciplinaire HAL, est destinée au dépôt et à la diffusion de documents scientifiques de niveau recherche, publiés ou non, émanant des établissements d'enseignement et de recherche français ou étrangers, des laboratoires publics ou privés. 


\section{A Filter Affinity Transfer Method for the Analysis of Rheumatoid Factors

\author{
Pierre Aucouturier, Jean-Paul Maillochon, Guy Joseph-Théodore, \\ Françoise Duarte, and Jean-Louis Preud'homme \\ Laboratory of Immunology and Immunopathology (CNRS URA 1172), \\ Poitiers University Hospital, Poitiers, France
}

\begin{abstract}
Transfer of serum proteins separated by thin layer agarose electrophoresis onto nitrocellulose sheets precoated with purified human polyclonal lgG followed by revelation with enzyme-coupled anti- $\mu$ or anti- $\alpha$ antisera resulted in the specific detection of rheumatoid factors (RF) belonging to the $\lg M$ or $\lg A$ classes. Mono- or polyclonality of such RF can be evaluated from the patterns of the
\end{abstract}

blots (sharp bands). In addition, their light chain type can be determined using affinity filters coated with a $\gamma$ heavy chain disease protein or with IgG Fc fragments. This simple and rapid procedure allows an easy characterization of monoclonal RF, even if they are present in minute amount amongst polyclonal RF as in certain sera from rheumatoid arthritis patients.

Key words: anti-IgG antibodies, monoclonal immunoglobulins, Western blotting, affinity blotting, rheumatoid arthritis

\section{INTRODUCTION}

High level rheumatoid factors (RF) are present in the serum of patients with various autoimmune diseases, especially rheumatoid arthritis (RA), the Sjögren's syndrome and idiopathic mixed cryoglobulinemia. On the other hand, a strikingly large proportion of serum monoclonal immunoglobulins (Ig) displays a RF activity. Such monoclonal RF may belong to any of the three main Ig classes, predominantly IgM. They may result in clinical manifestations such as vasculitis, hypergammaglobulinemic purpura or symptoms due to type II cryoglobulinemia $(1,2)$. It is therefore of clinical interest to characterize serum monoclonal RF. Several procedures have been developed to analyse RF charge heterogeneity and light chain restriction. These methods are based upon the isolation of RF by affinity chromatography, followed by conventional immunochemical analysis or on the revelation by conjugated aggregated IgG of blots of zone electrophoresis or isoelectric focusing of serum proteins (2-5). Such methods are technically complex and time consuming and they can hardly be used in large-scale studies. Filter affinity transfer (FAT), which consists in a specific transfer of electrophoretically separated proteins onto ligands (antigens, antibodies, lectins) bound to a solid phase (6) offers an elegant altemative. It was previously used to detect small amounts of serum monoclonal Ig using anti-Ig antibody-coated filters (7) or to characterize, with antigen-coated filters, monoclonal Ig reactive with viral, proteic or gangliosidic antigens $(8-10)$.

We developed a rapid and easy method for the analysis of IgM and IgA RFby FAT after thin layer agarose electropho- resis. This inexpensive method is applicable to large-scale studies of the clonality of RF and to screening of monoclonal Ig for RF specificity.

\section{MATERIALS AND METHODS}

The principle of the method is to separate serum proteins by high resolution electrophoresis and to transfer them on an uncoated nitrocellulose sheet to characterize serum Ig using conjugated anti-Ig antibodies, as previously described $(11,12)$, and on IgG-coated nitrocellulose to specifically detect RF. Preliminary experiments allowed to determine technical conditions under which the same electrophoresis can be efficiently successively blotted onto uncoated and IgG-coated blots.

\section{Sera}

RF containing sera included 17 sera from RA patients and 4 sera which contained monoclonal IgM or IgA of known RF activity (3). As controls, we used a normal serum pool and 37 monoclonal IgM containing sera and a monoclonal IgA containing serum from patients with Waldenström's macroglobulinemia (WM), lymphoma or chronic lymphocytic leukemia (CLL) with no known or an irrevelant (cold agglutinin, anti-myelin associated glycoprotein, MAG) antibody activity of the monoclonal Ig.

Received June 28, 1991; accepted July 5, 1991.

Address reprint requests to Pierre Aucouturier, CNRS URA 1172, CHUR La Milétrie, BP 577, F86021 Poitiers, France. 


\section{Preparation of Affinity Filters}

Human polyclonal IgG were prepared from Cohn fraction II (Sigma, St. Louis, MO) by DEAE-trisacryl (IBF, Villeneuve La Garenne, France) chromatography in $10 \mathrm{mM}$ Tris- $\mathrm{HCl}$ $\mathrm{pH} 7.5$ buffer. The $\gamma$ heavy chain disease (HCD) protein Riv, which is a short $\gamma$ chain made up of the hinge region and of the two last constant domains of the $\gamma 1$ chain (13) and IgG $F c$ fragments prepared by papain digestion of a monoclonal IgGl $\chi$, were kind gifts of Dr. E. Mihaesco (Paris). Nitrocellulose sheets (HAHY 304, Millipore, Bedford, MA) were incubated for $1 \mathrm{hr}$ at room temperature with solutions of polyclonal $\mathrm{IgG}$ at $10 \mathrm{mg} / \mathrm{ml}$ in $0.01 \mathrm{M}$ phosphate, $0.15 \mathrm{M}$ $\mathrm{NaCl}, \mathrm{pH} 7.4$, buffer (PBS) or of the $\gamma \mathrm{HCD}$ protein or $\mathrm{Fc}$ fragments at $5 \mathrm{mg} / \mathrm{ml}$ in PBS and rinsed once with PBS. IgG filters were saturated by incubation for $1 \mathrm{hr}$ in $5 \%$ skimmed milk in PBS and rinsed in PBS. Saturation of $\gamma \mathrm{HCD}$ or $\mathrm{Fc}$ fragments filters required an additional step of incubation with a $10 \mathrm{mg} / \mathrm{ml}$ solution of bovine serum albumin in PBS (PBS-BSA). Such affinity filters can be stored at $-20^{\circ} \mathrm{C}$ for at least three months with no noticeable loss of antigenic activity.

\section{Filter Affinity Transfer}

Thin layer $(0.4 \mathrm{~mm})$ agarose electrophoresis of $2 \mu \mathrm{l}$ of serum diluted $1 / 20$ in saline was performed using the Paragon ${ }^{\mathrm{TM}}$ kit (Beckman, Gagny, France). A first short blotting onto uncoated nitrocellulose was performed under pressure $\left(15 \mathrm{~g}\right.$ per $\mathrm{cm}^{2}$ for 10 seconds). Then the IgG affinity filter was applied to the same agarose gel under the same pressure for 7 minutes. The uncoated nitrocellulose was saturated with $5 \%$ skimmed milk in PBS. Then, both types of membranes were incubated for one hour with alkaline phosphatase-conjugated anti- $\mu$ or anti- $\alpha$ antibodies (Biosys, Compiegne, France) diluted $1 / 500$ and $1 / 5,000$ in PBS-BSA, respectively, washed six times with PBS containing 0.05\% Tween 20 (Merck, Darmstadt, Germany) (PBS-Tween). Bound antibodies were revealed with $0.4 \mathrm{mM}$ tetrazolium nitroblue (Sigma), $0.4 \mathrm{mM}$ 5-bromo-4chloro-3-indolylphosphate (p-toluidine salt, Sigma) in $0.1 \mathrm{M}$ Tris, $0.1 \mathrm{M} \mathrm{NaCl}, 50 \mathrm{mM} \mathrm{MgCl}_{2}$, pH 9.5, buffer. The reaction was stopped in distilled water. Light chains were similarly detected on uncoated nitrocellulose or on $\gamma \mathrm{HCD}$ or $\mathrm{Fc}$ fragments FAT filters using conjugated anti- $\chi$ and anti- $\lambda$ antibodies (Sigma) or the monoclonal antibodies HP 6023 (anti- $\chi$ ) or HP 6024 (anti- $\lambda$ ) (both kind gifts of Dr. C. Reimer, Atlanta, GA) followed by revelation with alkaline phosphatasecoupled anti-mouse IgG antibodies extensively absorbed on human IgG (12), as above.

\section{Standard Immunoblots}

The sera were also analysed under our standard conditions of Western blotting $(11,12)$ : electrophoresis of sera diluted $1 / 50$ to $1 / 1,000$ according to serum Ig levels, pressure blotting for 10 minutes on uncoated nitrocellulose, and revelation by conjugates specific for the various Ig heavy and light chains.

\section{RESULTS}

RF were undetectable by FAT in normal serum pools (not shown). In contrast, FAT allowed an easy detection of RF in RA sera with RF titers as low as $1 / 40$ by the IgG-latex agglutination test and the Waaler-Rose reaction (Fig. 1) and in the sera containing monoclonal IgM or IgA with known RF activity (Fig. 2). It is worth noting that several RA sera (at least Nos. 3 to 6 on Fig. 1) clearly contained small amounts of homogeneous RF (narrow bands on the IgG-coated nitrocellulose). These narrow bands were undetectable by electrophoresis nor on standard immunoblots. As for monoclonal RF containing sera, comparison of the blots of the same electrophoresis onto uncoated and IgG-coated nitrocellulose allowed an easy identification of monoclonal RF. Monoclonal Ig lacking RF activity were consistently negative. In some of the latter sera, polyclonal RF or discrete narrow bands of monoclonal RF which were clearly distinct from the major monoclonal Ig were detectable, generally together with a weak $\mathrm{RF}$ activity by agglutination tests. The internal controls in the experiment shown on Fig. 1 are sera containing monoclonal IgM (lanes 1) or IgA (lanes 3) without RF activity. As other examples of specificity controls of the FAT, Figure 3 shows a CLL serum with no detectable RF by the latex agglutination test and Waaler-Rose reaction (this serum contained small amounts of a monoclonal RF which was otherwise undetectable) and Figure 4 the serum from a patient with WM and a peripheral neuropathy and an anti-MAG activity of the monoclonal IgM (latex agglutination test and Waaler-Rose reaction titers were $1 / 360$ and $1 / 40$, respectively).

In addition to their charge homogeneity, monoclonal RF may also be identified on the basis of light chain restriction using the $\gamma \mathrm{HCD}$ protein or IgG $\mathrm{Fc}$ fragments as antigen in the FAT. However, a correct saturation of the blots (and hence specificity) was more difficult to obtain than with IgG coated nitrocellulose and the specific staining of bound RF was not as strong.

\section{DISCUSSION}

We describe a new method for the characterization of RF which appears to be especially suitable for an evaluation of their monoclonality on the basis of charge homogeneity and light chain restriction. This method is simple and rapid and it does not need any sophisticated material or reagent, when applied to the detection of RF belonging to Ig classes other than IgG. It can be used on a large scale to screen monoclonal IgM or IgA for RF activity or to evaluate the mono- or oligoclonality of RF in inflammatory diseases. Conceivably, FAT could also be used to detect IgG RF, using Fc fragments as antigen in the FAT and antibodies specific for IgG Fab fragments as revelating antibodies, for instance. RF display a 


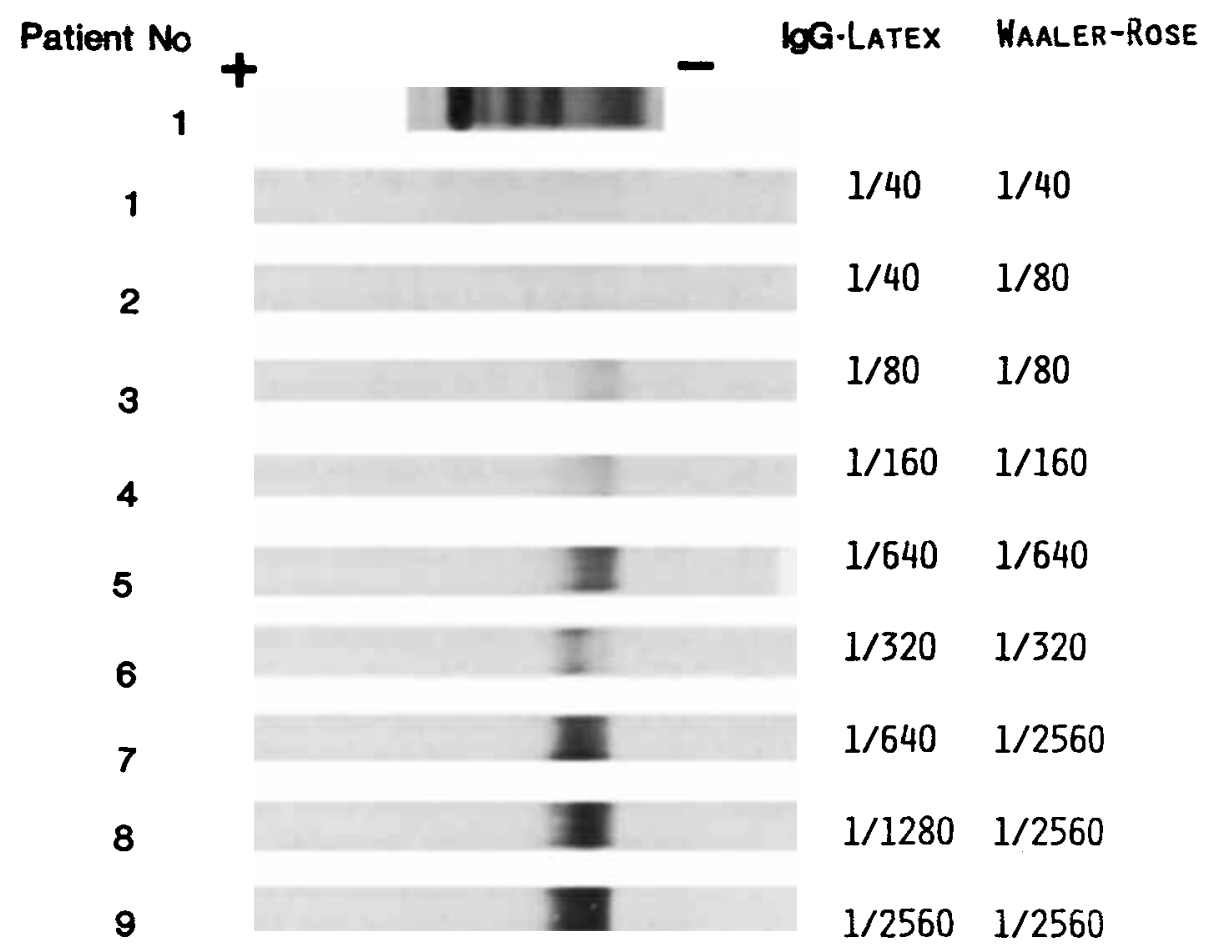

Fig. 1. FAT study of nine individual RA sera (revelation with anti- $\mu$ conjugate). The electrophoresis of the first RA serum is shown for comparison and the RF titers of the RA sera are indicated on the right part of the figure.
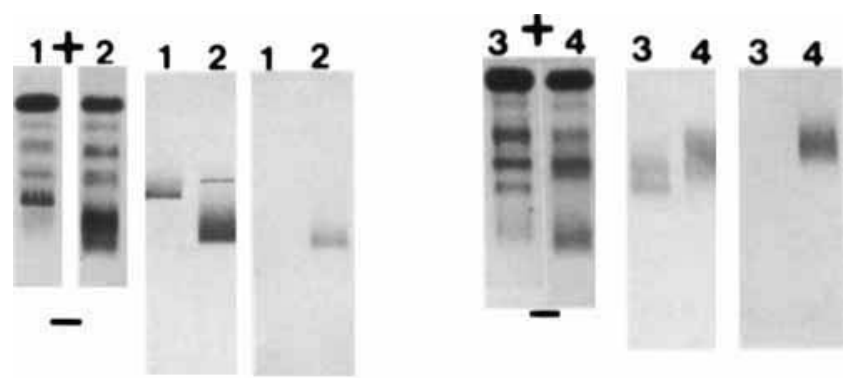

EP

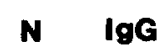

EP

$\mathbf{N}$

IgG

Fig. 2. Comparative study of monoclonal $\operatorname{IgM}$ and $\operatorname{IgA}$ with and without known anti-IgG antibody activity. The FAT blots are revealed with anti- $\mu$ (A) or anti- $\alpha$ (B) conjugates. Lanes 1 contain a WM serum without known antibody activity of the monoclonal IgM, lanes 2 a WM serum with a monoclonal IgM $\lambda$ displaying a RF activity (as shown by the study of RF isolated by affinity chromatography and by a latex agglutination test positive at $10^{-6}$ ), lanes 3 a control serum with a non-RF monoclonal $\operatorname{lgA}$ and lanes 4 the serum from a patient with hypergammaglobulinemic purpura and a monoclonal IgAK RF (3). EP, agarose electrophoresis; N, FAT experiment, normal uncoated nitrocellulose; IgG, FAT experiment, polyclonal IgGcoated nitrocellulose. stronger affinity for polymeric than for monomeric IgG. IgG bound to a solid phase are therefore well suited for their detection. Even IgG-RF complexes preexisting in vivo appear to be displaced enough for RF binding to the affinity filter to occur. Monoclonal IgM with known RF specificity yielded narrow bands by FAT whereas the monoclonal IgA from the patient with hypergammaglobulinemic purpura did not (Fig. 2B). This IgA was electrophoretically homogeneous when isolated but was diffuse in the whole serum due to high level of binding to polyclonal IgG (3). Residual complexes bound to the affinity filter likely explain the charge heterogeneity of this monoclonal IgA by FAT. This example illustrates a limitation of the method for evidencing the monoclonality of certain RF. The difference between this IgA RF and IgM $\mathrm{RF}$ is possibly due to a stronger affinity of the $\operatorname{IgA}$ for monomeric IgG which might reflect differences in the variable regions or/and polymerization of the monoclonal IgA (14). In such cases, other methods, such as affinity chromatography isolation of RF after immune complex dissociation (3), appear to be required.

Under the present technical conditions, FAT is specific, as shown by the negative internal controls with irrevelant WM sera. This specificity is dependent on the efficacy of the saturation of the coated nitrocellulose. Filters were easily and regularly properly saturated after coating with polyclonal IgG. 


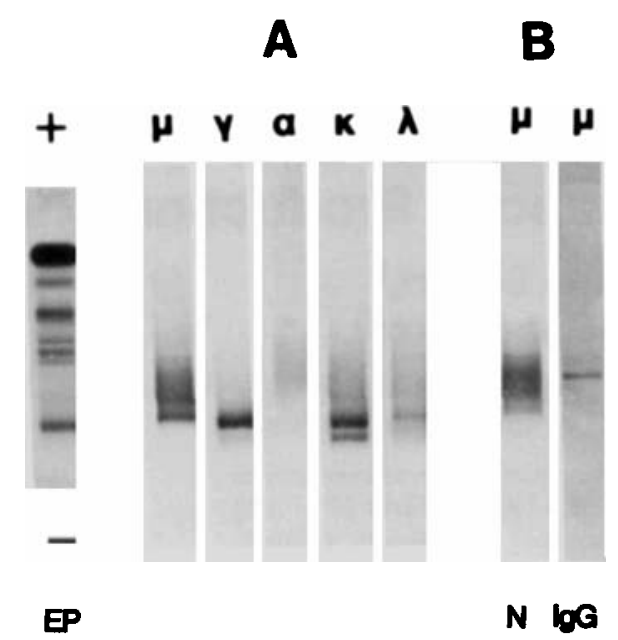

Fig. 3. Electrophoresis (EP), standard Western blots (A) and FAT (B, N, normal uncoated nitrocelllose; IgG, polyclonal IgG-coated nitrocellulose) of a CLL serum containing oligoclonal $\operatorname{Ig}\left(\lg M_{\chi}, \operatorname{IgM} \lambda, \operatorname{IgG\kappa }, \operatorname{lgG} \lambda\right)$ without RF activity by FAT and a narrow band of IgM anti-IgG that is undetectable by electrophoresis and on standard blots.

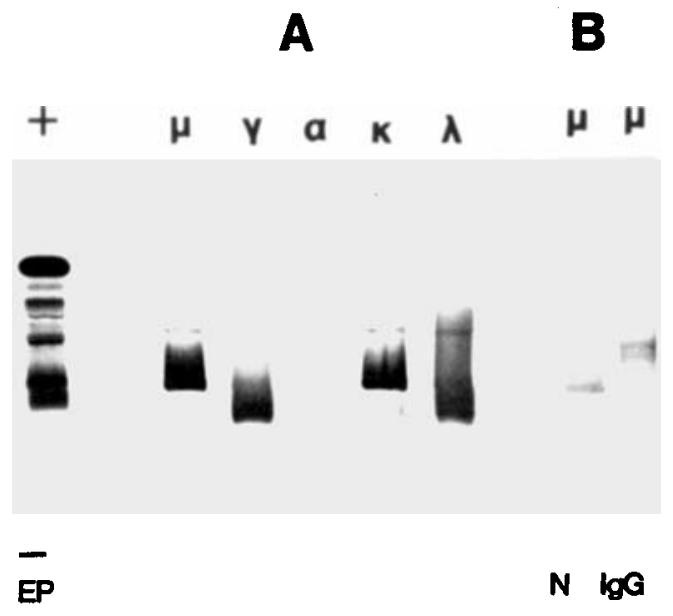

Fig. 4. Study of a WM serum with a monoclonal IgM anti-MAG. The latter monoclonal Ig is negative by FAT, as expected, but FAT discloses the presence of three narrow bands of IgM anti-IgG that are otherwise undetectable.

After coating with the $\gamma \mathrm{HCD}$ protein or with Fc fragments, an additional saturation step was required. There is, hence, clearly a need to control the binding specificity of every newly prepared affinity filter. In fact, we include an internal control using a WM serum with no RF activity of the monoclonal IgM in every experiment.

FAT detects polyclonal RF in RA sera with RF titers as low as $1 / 40$ by agglutination tests. Being a solid phase assay, it is likely to detect monomeric IgM RF which might be present in certain RA sera and do not yield positive agglutination reactions (15). It is not sensitive enough to detect $R F$ in normal sera, which is rather an advantage in clinical terms. FAT is highly resolutive, and narrow bands of IgM with RF activ- ity can be detected in the serum of patients with immunoproliferative disorders or even with autoimmune disease. Such oligoclonal RF are likely present in minute amounts since they were undetected by standard immunoblotting which allows the identification of monoclonal Ig in concentrations as low as $25 \mu \mathrm{g} / \mathrm{ml}$ (11). The finding of homogeneous RF amongst polyclonal RF in autoimmune processes was not unexpected but its significance remains to be established $(1,2,4,5)$. In the present study, we merely examined technical parameters but in the near future we intend to apply FAT to the screening of a large number of sera from autoimmune patients to evaluate the precise incidence of oligoclonal $\mathrm{RF}$ under such conditions.

\section{REFERENCES}

1. Carson DA, Chen PP, Fox RI, Kipps TJ, Jirik F, Golfien RD, Silverman G, Radoux V, Fong S: Rheumatoid factors and immune networks. Annu Rev Immuno] 5:109-126, 1987

2. Shakib F (ed): Autoantibodies to immunoglobulins. Monogr Allergy 26:1-81, 1989.

3. Preud'homme JL, Duarte F, Aucouturier P: Isolation of monoclonal theumatoid factors in hypergammaglobulinemic purpura. Diagn Immunol 2:219-223, 1984.

4. Chu JL, Gharavi AE, Elkon KB: Spectrotypic analysis of IgM and IgA rheumatoid factors. Clin Exp Immunol 63:601-607, 1986.

5. Bouvet JP, Pillot J: Restricted heterogeneity of polyclonal rheumatoid factors. Arthritis Rheum 30:998-1005, 1987.

6. Erlich HA, Levinson JR, Cohen SN, McDevitt HO: Filter affinity transfer. A new technique for the in situ identification of proteins in gels. $J$ Biol Chem 254:12240-12247, 1979.

7. MacLachlan R: Monoclonal immunoglobulins: affinity blotting for low concentrations in serum. Clin Chem 35:478-480, 1989.

8. Dörries R, Ter Menlen V: Detection and identification of virus-specific oligoclonal $\mathrm{IgG}$ in unconcentrated cerebrospinal fluid by immunoblot technique. J Neuroimmunol 7:77-89, 1984.

9. Cruz M, Olsson T, Ernerudh J, Höjeberg B, Link H: Immunoblot detection of oligoclonal anti-myelin basic protein IgG antibodies in cerebrospinal fluids in multiple sclerosis. Neurol 37:1515-1519, 1987

10. Jauberteau MO, Cook JM, Drouet M, Preud'homme JL: Affinity immunoblotting detection of serum monoclonal immunoglobulins reactive with glycosphingolipids. J Immunol Methods 134:107-112, 1990.

11. Aucouturier P, Capella M, Briault S, Danon F, Intrator L, Preud'homme JL: Caractérisation des immunoglobulines monoclonales dans les liquides biologiques par immunoempreinte sur nitrocellulose. Rev Inst Pasteur Lyon 20:147-153, 1987.

12. Briault S, Courtois-Capella M, Duarte F, Aucouturier P, Preud'homme JL: Isotypy of serum monoclonal immunoglobulins in human immunodeficiency virus-infected adults. Clin Exp Immunol 74:182-184, 1988.

13. Mihaesco E, Guglielmi P, Brouet JC, Mihaesco C: Biochemical and biosynthetic studies of a crystallizable human 1 heavy chain disease protein. Scand J Immunol 18:145-151, 1983.

14. Schrohenloher RE, Koopman WJ, Moldoveanu Z, Solomon A: Activity of rheumatoid factors of different molecular sizes: comparison of autologous monomeric and polymeric monoclonal $\lg A$ rheumatoid factors. J Immunol 134:1469-1474, 1985.

15. Bonagura VR, Mendez L, Agostino N, Pernis B: Monomeric (7S) $\operatorname{IgM}$ found in the serum of rheumatoid arthritis patients share idiotypes with pentameric (19S) monoclonal rheumatoid factors. J Clin Invest $79: 813-818,1987$. 